

\section{The Relationship Between Accounting Practices and Effects of Financial Crisis in Turkey: A Case Study on an Oil Company}

\section{İsmail Erkan Çelik}

\section{Introduction}

The term crisis comes from the word krisis in Greek and Latin. The word crisis is used as a synonym for concepts such as recession and depression within social sciences. Within the economics literature on the other hand, it corresponds to those terms such as depression, recession, impasse or difficult period and generally refers to the totality of comprehensive problems that impact upon the current situation and the future of enterprises, occur all of a sudden, where the affected parties are usually late in taking precautions and that change the economic operation partially or completely.

As seen above, the term crisis has several definitions. However, most generally it is defined as the tense situation that cannot be anticipated and foreseen beforehand, where prevention and harmonization mechanisms remain inadequate and that threatens existing values, objectives and assumptions. Concepts such as stress, concern and panic are the feelings experienced during a crisis. "Crises refer to the fluctuations that occur outside the limits of acceptable change within prices or quantities in a commodity, service, factoring and foreign exchange markets" (Kibritçioğlu, 2000).

Crises have become even more prevalent as the capital system became more widespread with the effect of the first industrial revolution. This crisis also named as the production crisis in 1825, had a significant adverse impact on Great Britain. Respectively, the crisis in 1836 had included USA in the chain of countries affected whereas the following crisis that occurred in 1847 included almost all of the European countries. As a result of this crisis, production activities were adversely affected within the production industry, consumption levels were reduced and unemployment levels increased rapidly. Pursuant to this crisis, another crisis occurred in 1873 affecting Austria and Germany and continued until 1879. The end of the capitalist era and the start of the imperialist era are also marked with the crisis between 1900-1903.

1929 crisis which has a considerably differentiated scope and impact in comparison to the crises that occurred in the past, is also described as the "Great Depression". The underlying reason for this crisis was the collapse of the stock exchange and its destructive effects. In order to explain the crisis that occurred during that period, it would be appropriate to elaborate on it by using examples. While the unemployment levels were at 3.2 in 1929, it had escalated to 24.9 in 1932. Gross Domestic Product (GDP) decreased from 103 billion dollars to 56 billion dollars. This crisis impacted upon the entire globe. At the end of World War II, the crisis that occurred between 1970 and 1980 was the first global crisis witnessed and this ten-year period is characterized as the "lost ten years". During this period, 15 million people were left unemployed and 10 million people had to manage by undertaking short-term, temporary works.

During the 1990s and 2000s, numerous crises were witnessed across the globe. The most important of these crises include the following:

- Crises affecting the Exchange Rate Mechanism (ERM) in the European Monetary System between 1992-1993

- Tequila Crisis that occurred in Latin America between 1994-1995 pursuant to the crisis in Mexico

-Currency and banking crisis that took place in 19941995 in Turkey

- Financial crisis that started in Thailand, Indonesia, South Korea and Malaysia in 1997-1998 and the impacts of which extended to several countries outside the region including other Asian countries first and other OECD countries afterwards

- Crises that occurred in Russia and Brazil in 1998 in parallel to the Asian crisis

- Currency and banking crises that occurred in November 2000 and February 2001 in Turkey

- Financial crisis that started in 2001 in Argentina and caused a deep economic and social collapse with its effects still on-going

After the 1980s, crises have occurred consecutively due to the effects of globalization and it has come to such a point that first, second and third crisis models were developed to explain the crises experienced over the last thirty years and scholars had to develop a new model to elucidate this crisis which occurred pursuant to the crisis in 2008 . 
Economic crises are classified in two categories as real economy crises and financial industry crises. These two crises also affect different industries. We can list real economy crises as inflation crises, recession crises and unemployment crises. Financial crises on the other hand can be categorized as banking, monetary, foreign debt and systemic financial crises. These crises are generally successive. For this reason, they cannot be distinguished from each other with very clear distinctions.

Financial crises are referred to as the panicking experienced from a financial perspective and the consequences of these panics or the boom of financial prices. Financial crises lead to the failure of the financial markets to perform their functions in an effective manner. Naturally, severe shrinkages occur in the volume of economic activities. Along with the numerous common characteristics of financial crises, they also have distinguishing features. The common point of all financial crises is evident in their cost creating features. The Classification of the Concept of Financial Crisis can be described as the following:

-Currency Crisis

-Banking Crisis

-Foreign Debt Crisis

-Systemic Financial Crisis

On the other hand, banking crises are analyzed within the framework of the increase in nonperforming loans, deterioration in bank balances, decrease in the loan demands from the real economy and the shrinkage in commercial loan periods as well as sudden and sharp fluctuations in the securities markets. As the loan periods for the debts owed by commercial banks cannot be extended or as these banks fail to meet the sudden withdrawal requests in demand deposits, liquidity problem occurs and this is followed by their announcement of bankruptcy. The reasons that lead to a banking crisis are diverse. The irresponsible attitudes of the banks, the weakness of the banking system and the fragility of financial markets are among the primary reasons.

It is also believed that the currency crises have an impact on banking crises. Since the 1950s until the 1960s, banking crises have not been widespread. However, after the 1970s and until the present day, they have started to occur simultaneously with currency crises. For example, currency crises have been witnessed between 1970 and 1985 and during the same period, banking crises have also become more abundant. However, banking crises continue for a longer period and they are more severe compared to currency crises.
Currency crisis refers to the rapid loss of value in a country's currency. The significant aspect of currency policy is the foreign exchange rate applied by that country. If a country implements the fixed exchange rate system, then a rapid escalation in the devaluation rates of the designated country will be regarded as a crisis, whereas if the flexible exchange rate system is valid, then significant levels of deviation from the market value in the exchange rate will be considered as a crisis. For example Frankel, Rose and Andrew (1996) indicate that a currency crisis occurs when the nominal depreciation rate of the national currency equals $25 \%$ and if this depreciation rate shows at least $10 \%$ increase compared to the previous period.

Currency crisis is also described as a foreign exchange crisis. A currency crisis also occurs when there is a sudden movement in foreign exchange rates and a sharp alteration in market movements. A currency crisis takes place especially in fixed foreign exchange systems when the market players suddenly shift their demands from the local currency to the foreign currency assets and the foreign exchange reserves of the central bank are depleted. The most important characteristic of the currency crises is reflected in the destructive impact of the expansion mechanism. For example, it was particularly evident in the most recent Asia crisis. The crisis initially started in a single country but afterwards it had significant effects on an important part of Southeast Asia due to the similar economic structures in the region and the high levels of commercial links. The development and expansion stage in the foreign capital flows towards these countries was followed by very severe and sudden reverse movements.

Foreign debt crises on the other hand refer to the incapability of a country to pay its foreign debts incurred by the public and/or private sector. It occurs when a country invigorates its domestic product with the foreign debts it receives, loses its capability to pay these foreign debts on a regular basis and announces that it will not be able to pay the principal amount and interests incurred for this debt. Foreign debt crises especially occur when the governments encounter problems in debt rollover and finding new foreign loans and as a result, the foreign debt amounts in question are restructured with new payment plans or the obligations are postponed" (Turgut, 2007). When the borrowing country cannot pay its debts, the lenders refrain from lending new loans and debt crises occur when they try to recover the debts that they have already given. If the public sector cannot pay the designated debt, then a significant downfall takes place in the private capital inflows and in fact, it can lead to a currency crisis. 
Systematic financial crises on the other hand encompass currency and banking crises and are defined as significant potential disruptions experienced in the capability of the financial system to perform its fundamental obligations in an efficient manner. Moreover, systemic financial crises are described as a shock that causes an interruption in the essential functions of the financial system such as asset valuation, loan allocation and payments.

Finance markets perform the following functions in an economic system. They steer funds to the decision-making units with productive investment projects effectively and accurately. Hence, they share the risks encountered by the investment projects of decisionmaking units and facilitate the flow of funds. Moreover, the financial system curtails the transaction and research costs incurred in financial markets and perform the function of ensuring efficient funds allocation. Along with this, it furnishes the increase of productivity in real economy and economic growth. Naturally, the financial system carries out its functions through financial markets and institutions. For example, the banks experiencing difficulty in repayment or interruptions in repayment, sudden collapses in the securities and the systematic occurrence of these lead to systematic crises. These crises afterwards encompass currency and banking crises. Systematic crises that develop due to the designated reasons create an adverse effect on the real economy (output and employment). When there is a systematic disruption, output (production) losses occur in that country, economic losses grow, national income decreases and the country diverges away from economic efficiency.

There are also several accounting-based reasons in the occurrence of a financial crisis. When we investigate the accounting-based reasons of a financial crisis, we observe that the accounting based reasons of the crisis stem from abuse and exploitation in accounting. Put differently, it originates from the characterization also referred to as "mine fields in accounting". We can briefly list the accounting based reasons as the following:

1. Accounting diverging from the primary principles, rules and concepts,

2. Inability to achieve full independence in accounting standards and those institutions regulating these standards,

3. Creative accounting practices (creative accounting),

4. Financial reports with transparency problems, which do not reflect reality,

5. Problems with fair value valuation,
6. Failures in supervision and misleading auditing reports,

7. Diverging away from the concepts of prudence and conservatism,

The transactions related to the execution of an enterprise and applications are materialized with the fundamental principles, rules and concepts of the accounting. In case of non-compliance with these principles, rules and concepts, they lead to the occurrence and expansion of global financial crises. It is believed that the failure to comply with accounting principles underpinned the global crisis that took place in 2008. Former Chairman of TÜRMOB Masum Türker indicated that crises are grounded in non-compliance with accounting and therefore the solution has to be sought in accounting as well (Türker, 2009).

Wrongful accounting practices carried out by those enterprises which announced their bankruptcy are listed below:

-One of the fundamental concepts of accounting is social responsibility. However, disregarding the interests of the society in accounting practices and processes, and diverging away from the concept of social responsibility,

- Moving away from the concept of personality when the enterprise's treasury and/or the treasury of the enterprise's owner and/or partners are not separated,

- Alienation from the monetary (money measurement) concept of accounting using differences in foreign exchange rates and arbitrage methods for their own advantage,

- Estrangement from the concept of full explanation (full disclosure) with non-transparent practices,

- Diverging away from the concept of objectivity by being an instrument of the enterprise management's demand to manipulate financial reports,

- Moving forward from the concept of cost base by revealing the assets with the values which do not reflect reality through the employment of market value method,

- Practicing fraud by registering unrealized revenues,

Accounting practices of bankrupt companies also contradict ethical rules and standards along with the legislative provisions. Apart from all these, it is understood that they stem from considerably conscious actions which contradict the interests of the society and general ethics norms. It is observed that several enterprises trick investors, creditors, state and the society through fraudulent financial reporting and lead to crises. 
Small enterprises also generally show their assets and profit less than the actual values; whereas large enterprises present their assets and profits more than the actual values. The objective of small enterprises is to avoid paying taxes or reducing the amount of tax they are required to pay. Large enterprises on the other hand, aim to find more funds (loans and capital). Large enterprises demonstrate the financial status of the company differently to the public. What is interesting is that, actually all of these firms seem to comply with the accounting standards and legislations. But enterprises perform these contradictory acts through creative accounting practices.

Auditing institutions, credit and finance corporations as well as credit rating institutions are also involved in these tricks used by the enterprises. For example, the relationship between the fluctuations in the US market and accounting in 2008 caused the interrogation of the accounting institutions and standards pursuant to the global crisis. These kinds of effects or pressures applied to financial institutions such as IASB (International Accounting Standards Board) or FASB (Financial Accounting Standards Board). These organizations had also become significant parts of debate.

Creative accounting, on the other hand, is defined as performing measurements and making presentations using the existing flexibilities in accounting provided that they stay within the legal limits and hence accommodating the priorities of those who prepare these data instead of the requirements of those parties using the accounting information. This practice is generally carried out by enterprises in order to change or conceal unwanted results of financial circumstances and activities.

It is also argued that creative accounting practices provide some advantages to firms, such as low financial cost and higher stock (share) values in the market. That is why specific companies are in favor of creative accounting, although it is not a correct action. If we consider it in the short-term, it is true that creative accounting has positive impacts. However, in the longterm, creative accounting causes disadvantageous and difficult situations which are hard to recover. The "misrepresentation" activities of the enterprises willing to use the gaps and flexibility in creative accounting practices lead to the occurrence of the global crises. The enterprises willing to acquire advantages in the shortterm have encountered various problems in the longterm. General Motors, America has taken advantage of the options and flexibilities offered by creative accounting practices which completely comply with accounting practices. Prior to going bankrupt in 2009, it had used creative account practices and it had announced its loss for 2006 and 2007 as 1 billion USD, which was actually 3 billion in reality. In the same manner, it had announced its loss for 2008 as 16.8 billion USD even though it was actually 30.6 billion. The company had gone bankrupt in the long-term while it aimed to acquire advantages in the short-term. General Motors (GM) was re-structured after the 2009 bankrupt and a new GM was formed. Although General Motors owned $60 \%$ of the automobile market share in the US in 1960, this rate was reduced to $25 \%$ by 2008 . Thus, it can be seen how several companies used creative accounting as an instrument of fraudulent financial reporting while financial crisis circumstances were maturing and had inflicted damage in return.

Auditing on the other hand refers to the investigation of whether financial reports are prepared, shared and reported in accordance with accounting principles, standards and regulations. However, auditing weaknesses occur when the transparency principle is neglected in accounting practices. Transparency and auditing weaknesses have inflicted significant damages on the road to a crisis (Aysan, 2009). Complete success could not be attained in accounting measurement methods. This omission had led to those circumstances where financial assets could not be priced accurately.

The fair value approach, on the other hand, originated from the demands of the financial statement users (investors, executives, employees, state, lenders, customers, suppliers and wide masses of public) to reflect the data provided within the financial statements in an accurate manner. The fair value approach has taken the market price as a basis. Fair value is defined as the sales value between the bidders (a buyer and a seller) in a mutual negotiation environment. Put differently, fair value accounting functions without any problems if the assets are considered with their real prices, however in those situations when the prices regarding the assets cannot be determined accurately in the market, then it leads to facing certain challenges. In a crisis environment, assets and debts were evaluated freely by the companies as designated reliable prices were not present in the market, however this situation led to the further deterioration of the financial crisis. (Can, 2010).

For example; prior to the global crisis in 2008, fair value approach was employed for subprime valuation. Securities predicated on subprime mortgage 
loans were being priced by performing negotiations under ordinary conditions. However, during this crisis period, this pricing method lost its transparent characteristic and started to be corrupted. The use of market prices as a fair value also challenged the performance of valuation in this period where pricing has become harder, liquidity and trust were lost. It is generally acknowledged that the fair value accounting system plays a role in the deepening of this global crisis at the minimum.

It is so far discussed how diverging away from and abandonment of certain fundamental accounting concepts affected the crisis. Another accounting concept on the other hand is prudence and conservatism. The most recent crisis that occurred also revealed that there was a divergence from the concepts of prudence and conservatism as in the case of other accounting concepts.

The concept of prudence and conservatism refers to the ban on the reporting of unrealized revenues and profits and registering these as expenditure while reserving the equivalent amounts for the existing or potential losses. As they object to reflecting the assets and profits more than their actual value, it is characterized as conservative. This accounting concept ensures the permanence of an enterprise. Conservatism concept in accounting also refers to accountant being careful, cautious and allocating necessary reserve funds for unexpected situations. As an example, allocating provisions for doubtful receivables is a requirement parallel to the conservatism concept in accounting. Thus, divergence from this concept puts the enterprise in a difficult situation. The significance of this concept is particularly recognized during the shrinkage and growth periods (cyclical fluctuations) in the economy. For example, the practices implemented in the US markets during the most recent crisis were related to divergence from the concepts of prudence and conservatism. The companies which move away from these concepts go as far as bankruptcy. Well known firms which did not comply with the conservatism concept during the crisis period in the US can be listed as WorldCom, Enron, Global Crossing, Adelphia and Kmart.

\section{Literature Review}

When we evaluate the reasons for global financial crises from an accounting perspective, we had discussed that these reasons were comprised of exploitation, abuse and frauds in accounting. The research conducted by Güler Manisalı Darman (2004) addresses how certain companies trick every segment (creditors, employees, contractors and the entire society) associated with the investors and themselves by applying tricks and fraudulent practices in accounting. The situation when accounting practices lead to a crisis is referred to as "mine fields in accounting". What are meant by mine fields in accounting is those circumstances that violate accounting rules and principles such as intentional fictive income, boosting losses and profits, concealing debts and falsifying tables.

The research carried out by Ahmet Vecdi Can (2010) on the other hand connotes that, the former Chairman of TÜRMOB Masum Türker (2009) indicated that the foundation of a crisis has to be sought in noncompliance with accounting principles and the solution could only be found in the accounting itself while making an assessment on the global crisis. We can reinforce the situations where divergence from the main principles and concepts of accounting lead to a crisis with specific examples from real life: WorldCom showing 3.8 billion expenses as capital, Enron selling its assets to private purpose companies off the balance sheet, boosting the balance sheets of the companies in China by the state prior to privatization and the occurrence of the Parmalat scandal (where the debts were concealed, offbalance financing were used and company owners had deposited 500 million dollars in their own private companies).

There are several reasons which give rise to financial crises. Ahmet Gökgöz (2012) had described the extent to which these reasons were accounting based as the following: One of the most important reasons underlying the impact of financial crises on several individuals and states and reaching a global scale is seen as the fraudulent practices of those enterprises conducting business in different parts of the globe, where they used misleading financial reports to trick the users of financial statements worldwide. Here the important point is, all of the lies put forth with the financial statements actually comply with accounting legislations, rules and standards. Therefore, the financial statements in question are actually able to pass auditing and it is confirmed that they reflect the truth. In this context, these crises are actually referred to as accounting crises. Even though it is highlighted that a crisis is accounting based, it would be appropriate to assert that it is actually the enterprise executives and accounting professionals failing to comply with these rules who cause these crises to occur. Within the research conducted by Ahmet Gökgöz (2012), the author designates that the accounting tricks in those companies such as Enron, WorldCom, Adelphia, Xerox, Tyco and Parmalat at the beginning of the 2000s as well as the fraudulent practices of several executives of various enterprises prior to the global crisis 
in 2008 led to numerous companies to go bankrupt and several beneficiaries to suffer from losses.

According to the studies of Neslihan Topbaş (2009), the primary objective of the fair value accounting system is to manifest the losses that might arise in case the risks undertaken to ensure income are materialized in the best possible manner and introduce the relevant institution to the market players in accordance with these information. The extreme optimism of lenders, borrowers and investors with regard to the housing market and the affiliated markets and the failure of economic policies, banking regulations, company administrations and similar other regulatory mechanisms to manage this optimism as required had become the main factors in the formation of the crises.

The misleading and unreliable characteristic of financial reports along with the problems encountered during the auditing of these reports predominantly led to these crises. In a research conducted by P.J. Barrett (2010), it was denoted that along with the misleading financial reports and data manufactured with the use of accounting systems, the misrepresenting auditing reports which confirmed their accuracy and reliability played a significant role in the formation of the crises and therefore, these crises led to an increase in the prevalence of the gap for auditing expectations worldwide and escalated the debates with regard to the auditing profession. Pursuant to the crises experienced, auditing institutions started to be questioned.

In regards to an article published by the Ministry of EU Affairs (AB Bakanlığı) (2011), this issue is tackled. During the pre-crisis period, the failure to subject the financial system sufficiently to auditing and the delay in adopting preventive measures resulted in the further escalation of the crisis. Also, after recovering from the initial shock caused by the crisis, the qualifications and competence of the regulatory and supervisory structures in the industry started to be interrogated. The artificial inflation of financial statements instead of reflecting the facts is considered as a significant transparency problem. These kinds of practices which are not compatible with the concepts of full explanation (full disclosure) and transparency among the primary concepts of accounting are regarded as the most important reasons that generated the crisis.

In a report published by the United Nations Conference on Trade and Development (UNCTAD) in March 1999: "The failures of the financial institutions and companies in the Far East result from the companies which are under the burden of excessive debts, tendency of the private sector to obtain high levels of foreign debt and the omissions in transparency and accountability. The omissions in financial explanations also have a significant share in this. The shortcomings with regard to the rules applied to the statements indirectly contributed to internal auditing problems and the flawed and inappropriate risk management practices of the banks and companies" (UNCTAD, 1999).

This problem and statement is also supported with another research. Spence (2008) and Daştan (2009) underline that the source of the crisis that occurred in the US in 2008 can also be attributed to the problem of transparency. According to this research, "Whereas the risk had to be expanded as a result of the inflated and exploding balloon of assets, it was actually extreme transparency problems related to complex bonds and derivatives and the inadequate auditing structure employed to ensure stability, which occurred over time which increased the systematic risk carried by excessive debt."

Finally, while discussing the accounting based reasons of a crisis, Akerlof and Romer (1993) who have been awarded with a Nobel Prize point out that, inadequate accounting systems, weak legal regulations and low levels of fines lead to bankruptcy for profit. Another scholar with a Nobel prize, Stiglitz (2008) stated that "The problems are underpinned by the bad decisions and auditing mistakes of the banks". His statement supported the previous arguments by considering the crises that occurred at different periods as having the same basis.

\section{Research and Methodology}

The research contains the fundamental data of a mid-size company during the pre-crisis period between 2006 and 2008 and the post-crisis period between 2008 and 2010. For this research, interviews were conducted with the company's accounting officer and certain basic data were obtained. These data include the number of products, number of employees, product distribution and the financial turnover (revenue) of the enterprise prior to and pursuant to the crisis.

First of all, it is wise and correct to discuss the management information, mission, vision administration structure and activities of the company that the research is conducted on. The real name of the firm subject to this research is confidential, thus will be indicated as $\mathrm{XYZ}$ company in the following sections of this article. 
The company with trade name XYZ was established as a limited liability company in 1991. The company's founding capital was $10.000 \mathrm{TL}$. The firm had increased its capital to 1.000 .000 TL with a capital increase in 2008. In 2010, a capital increase was not observed in the company's owner's equity. The enterprise has a single headquarters, which is located in Istanbul.

The company's vision is to develop the product quality and types constantly in order to respond to the customers' requirements, to work in collaboration with the business partners in order to procure their own products in the most effective and efficient manner, to create a working environment that would maximize the creativity and productivity levels of all of the employees and to ensure the sustainability of environment, to keep the promises given to the customers, business partners and employees, and to comply with business ethics rules at all times.

The enterprise has an official organizational diagram as shown below. However, the mentioned organizational diagram is not fully functional.

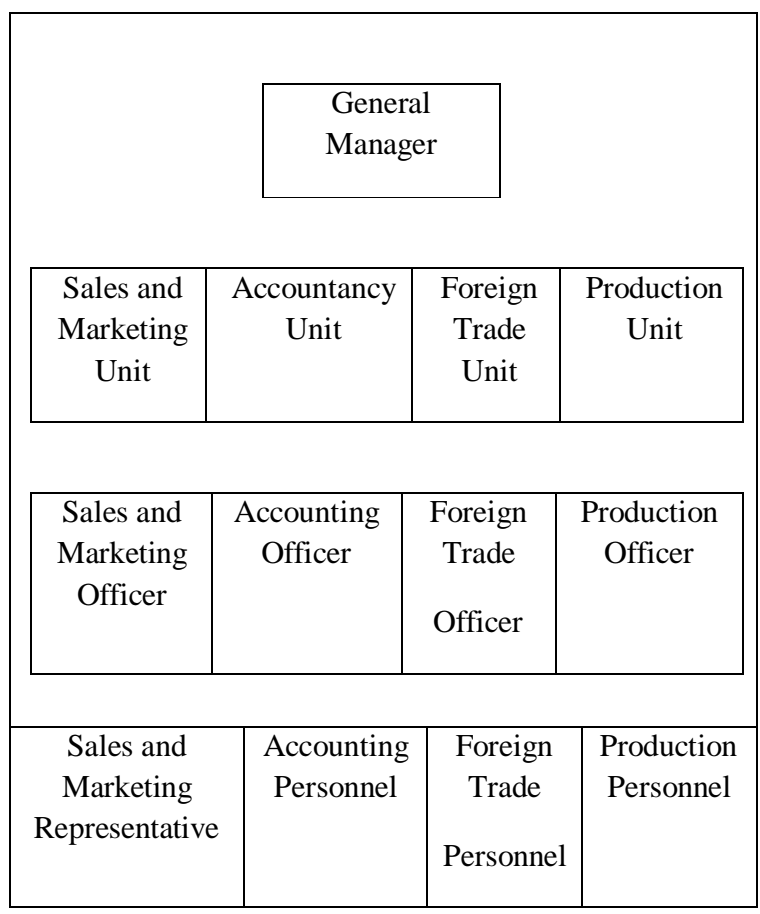

Figure 1. Organizational Diagram of XYZ Enterprise

$\mathrm{XYZ}$ is a company that is completely specialized on the petroleum equipment industry. Conducting business activities both as a producer and as a distributor company on petroleum equipment which is its main field of activity, XYZ has a wide range of products including the infrastructure installations of stations, all of the pumping parts, LPG pump equipment, alternative (CNG,
Hydrogen) pump equipment, cryogenic valves and chemical cleaning products.

During the years when it was first founded, XYZ manufactured products predominantly for the local market and provided services for the Petroleum and LPG industries with regard to pump parts such as hinges, breakaway, flow controls and guns. Since 2000, XYZ started to conduct business on the infrastructure installations on stations with the important representations it has acquired. Owing to the successful applications it has carried out within this field, XYZ has become one of the leading companies in the industry and implemented its vision which entailed becoming an "energy company" within the natural gas industry where it was first engaged in 2002.

Moreover, the company had its production and system quality confirmed after it was certified with an ISO 9001 certificate in 2007.

In the following sections of this paper, product portfolio of XYZ over the years, personnel profile of ACC Enterprise on a yearly basis, yearly sales turnover of ACC, post-crisis product portfolio of XYZ, 2006-2008 Pre-Crisis and 2008-2010 Post-Crisis Product Distribution (\%) for XYZ and Post-Crisis Employee Portfolio of XYZ are discussed as a part of research methodology. The mentioned data are collected by conducting an interview with XYZ firm's accounting officer.

Table 1: Product Portfolio of XYZ over the years

\begin{tabular}{|c|c|c|c|}
\hline & 2006 & 2007 & 2008 \\
$\begin{array}{c}\text { NUMBER (TYPE) OF } \\
\text { PRODUCTS }\end{array}$ & 1396 & 1533 & 1729 \\
\cline { 2 - 4 } & & & \\
\hline
\end{tabular}

As the company expanded its customer portfolio, it has also adopted the policy of expanding its product portfolio. Especially in 2007, the company has taken the necessary steps to expand its product portfolio further initiating new product research studies. For this reason, if we were to consider the product portfolio of the company based on the years, while it was 1396 in 2006, we observe that it increased to 1729 in 2008 . Accounting officer of XYZ indicated that, the firm does not have a policy to use excess short-term and long-term bank credits. Instead, relying on owner's equity is a better strategy and priority for XYZ. Accounting officer of the company stressed that, accounting practice of relying on owner's equity rather than short-term and long-term bank credits helped the firm to overcome the negative effects of 2008 financial crises. 
Table 2: Personnel Profile of XYZ Enterprise On a Yearly Basis

\begin{tabular}{|l|c|c|c|}
\hline & 2006 & 2007 & 2008 \\
NUMBER OF \\
EMPLOYEES & 33 & 39 & 46 \\
\cline { 2 - 4 } & & & \\
\hline
\end{tabular}

While the number of employees was 33 in 2006, it increased consistently until the year 2008. The increase in the number of employees is concerned with the company starting to manufacture a group of products, ensuring proximity to the market and its ability to fulfill customers' demands in due time. During the period prior to the crisis between 2006 and 2008, the company adopted a growth policy which entailed increasing the number of employees in order to expand its product portfolio and its market share as a result. According to the accounting officer interviewed, employee termination is only a solution in the short-run, but it leads to several disadvantages in the long-run. Because, employee turnover ratio hurts the reputation of organizations, decreases organizational commitment and increases expenses, in line with the statements of accounting officer. In XYZ, employee salaries are paid electronically with EFT and no employee receives his/her wage as cash. So, it is a top principle for XYZ to pay accurate taxes to the government. Also, seniority indemnities are calculated correctly and provisions for employee termination benefits are computed accordingly. Thus, XYZ firm completely abides to the conservatism concept. Accounting officer of XYZ underlined the fact that, following and implementing general concepts of accounting helped the firm to protect from undesirable effects of financial crises.

Table 3: Yearly Sales Turnover of XYZ (TL)

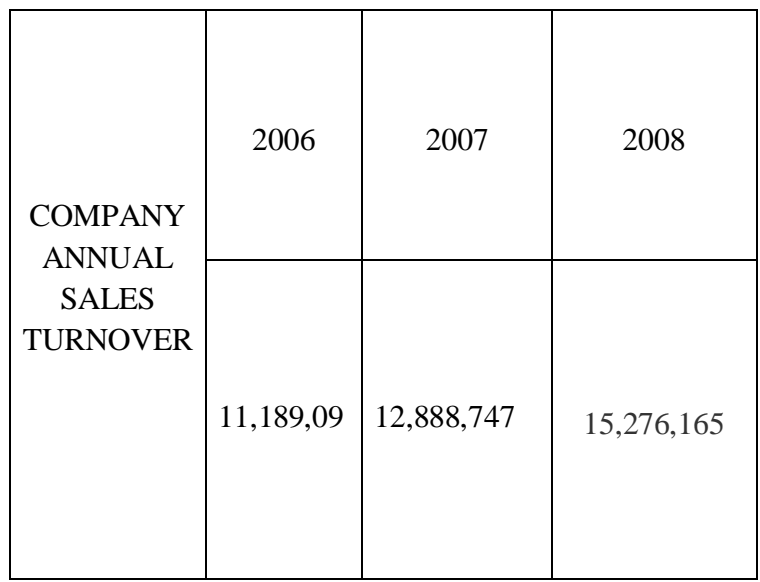

While the company's yearly sales turnover was $11,189,09$ TL in 2006, it gradually increased every year and reached to $15,276,165$ TL in 2008. In this context, the strategy which involved product diversification and reaching new markets adopted by the company as its growth policy between the years 2006 and 2008 had a positive impact on sales and sales sum. Accounting officer of XYZ explained that, ever increasing annual sales turnover of firm (TL) strengthens the financial situation of firm and also empowers the owner's equity structure. Thus, financial risk of XYZ is never high and that also helps the company to take advantage of external financing cheaper with better conditions. Transparent financial statements of XYZ reflect all the accounting indicators accurately. So, according to the opinion of XYZ's accounting officer, correct accounting practices always avoid the negative consequences of difficult situations during financial crises.

It is also observed that, the pre-crisis period of 2006-2008 is the period when the company started to grow and secured a place for itself in the market while making an established name for itself. Afterwards, the crisis which shook and affected the entire world occurred in 2008. However, when we examine the post-crisis data that we are in possession of, we observe that the company turned this crisis into an opportunity with the successful accounting and financial policies it adopted and had the least amount of loss and actually achieved growth during this period. Indicators prove that, the company was only slightly affected from the crisis during the 2009-2010 post-crisis period, but it reached to a certain desired point after a period of maturing.

Table 4: Post-Crisis Product Portfolio of XYZ

\begin{tabular}{|c|c|c|c|}
\hline & 2008 & 2009 & 2010 \\
NUMBER (TYPE) \\
\begin{tabular}{c} 
OF PRODUCTS \\
\cline { 2 - 4 }
\end{tabular} & 1729 & 1468 & 1672 \\
& & & \\
\hline
\end{tabular}

As it can be understood from the table, the company did not adopt a management approach which is governed by panic in the crisis environment of 2008 . Even though there was a decrease in the number of products in 2009, it further increased its product range in 
2010 which was growing on a yearly basis since 2006. The Company's accounting officer explains the decline witnessed in 2009 as the following:

"Naturally, we were affected by the crisis period like every other enterprise. However, we experienced this at the minimum level. Naturally, the accounting policies and strategies followed by the company had a significant role at this point. For example, product distribution was changed. We started to concentrate more on production pro rata. This was a positive thing for us due to the foreign exchange rates that increased during the crisis period. We were mostly focused on carrying out production ourselves."

Table 5: 2006 - 2008 Pre-Crisis and 2008-2010 PostCrisis Product Distribution (\%) for XYZ

\begin{tabular}{|c|c|c|c|c|c|}
\hline PRODUCT & 2006 & 2007 & 2008 & 2009 & 2010 \\
\hline $\begin{array}{c}\text { SELF } \\
\text { PRODUCTION }\end{array}$ & 13 & 19 & 24 & 31 & 36 \\
\hline $\begin{array}{c}\text { IMPORTATION } \\
\text { SPOP }\end{array}$ & 81 & 76 & 69 & 64 \\
\hline
\end{tabular}

According to Table 5, XYZ only produced 13\% in 2006 and imported 87\% in 2006. This situation improved in 2007 with $19 \%$ self production and $81 \%$ importation. Even during the crisis of 2008, self production increased to $24 \%$, while importation decreased to $76 \%$. In the following year (2009), self production of XYZ was 31\% and importation was $69 \%$. Finally, the most favorable situation was observed in 2010 with 36\% self production and 64\% importation. Table 5 above is an ideal indicator, which shows that $\mathrm{XYZ}$ firm was not affected by the financial crisis. The firm is actually experiencing a continuous positive trend, because it is now less dependent on importation compared to former years. From an accounting perspective, more self production and less imports help to prevent foreign exchange losses. If borrowing is existent in the case of imports, foreign exchange losses issue becomes more evident. Accounting officer of XYZ mentioned that, coordination among the accounting department and other departments in a firm such as the production department and marketing department is also crucial to give the correct decision concerning self production or importation. Thus, accounting practices are really like a medicine to defend from the unhealthy consequences of financial crises.

Table 6: Post-Crisis Employee Portfolio of XYZ

\begin{tabular}{|l|c|c|c|}
\hline & 2008 & 2009 & 2010 \\
NUMBER OF \\
EMPLOYEES & & & \\
\cline { 2 - 4 } & 46 & 43 & 49 \\
& & & \\
\hline
\end{tabular}

During crisis periods, austerity measures generally start from the personnel. However, even though the industry that the company is engaged in went through shrinkage during the crisis period, it is seen that XYZ did not believe there had to be shrinkage in their own activities. In this context, a significant amount of reduction did not occur in the number of employees. The number of employees was 46 in 2008. After a slight decline in 2009, number of employees started to escalate again in 2010.

As part of the exemplary practical research conducted, the company that we carried out the case study on successfully implemented the crisis management method using the right strategies before and after the crisis. The company also altered its product portfolio in order to protect itself from the increases in the costs during the crisis period. At this point, role of accounting in effective crisis management is also observed easily. So, correct accounting practices definitely lower the adverse effects of financial crises. $\mathrm{XYZ}$ started to perform the manufacture of the products that were advantageous. During the crisis period, even though some of the industrial enterprises were adversely affected, owing to the right steps that XYZ developed with regard to sales and collection, it survived through this period with the least amount of loss, thanks to smart accounting practices during financial crises.

During the post-crisis period between 2008 and 2010, the company continued to move forward without 
making significant changes. The company has acquired efficient and effective progress due to the diversification of the products, efficient cost management and the application of right strategies within the field of production. Accounting officer of XYZ said that, auditing and internal control applications are also critical accounting components besides standard accounting practices in order to minimize the negative effects of financial crises. Especially, the role and function of auditing as well as internal controls can never be neglected in terms of efficient cost management.

\section{Conclusion and Evaluation}

If we consider the financial crises, we can come across several reasons underlying them. We can provide several examples such as the disruption of macroeconomic equilibriums, the fragility of financial systems, inconsistency between domestic policies and the foreign exchange regime along with accounting principles.

The misuse of accounting principles caused the financial crises to lead to even more adverse results. As the companies conceal facts diverging from the concepts of objectivity, consistency, full explanation (full disclosure), conservatism, materiality and substance over form, financial crisis have a deeper impact. Also, use of unrealistic financial statements and auditors not complying with accounting ethics for the fulfillment of certain purposes carry crises one step forward.

The best explanation that would identify the crisis experienced as an accounting crisis came from Akerlof and Romer (1993) who were awarded with a Nobel Prize. They mentioned that, "Inadequate accounting systems, weak legal regulations and low levels of fines lead to bankruptcy for profit." Naturally, we cannot argue that the crisis is accounting based solely looking at this explanation. However, even it was initially caused by the disruption of macroeconomic equilibriums and the foreign exchange rates and domestic policies, it was further developed with the misuse of accounting principles.

If one of the reasons underlying a financial crisis is accounting, then the solution should be sought in accounting as well. In order to prevent all of the accounting practices that would lead to a crisis, accounting rules, regulations, methods and standards can be discussed and certain adjustments can be applied.
Prior to and pursuant to the financial crisis, company policies are extremely significant for their sustainability. Whereas some companies go through this period with the least amount of damage, some companies come to the point of bankruptcy. Prior to the global crisis that occurred in 2008, several companies suffered from losses and they even went bankrupt due to the accounting tricks they applied during this period. Enron, WorldCom, Adelphia, Xerox, Tyco and Parmalat and several companies can be given as an example in this regard.

The XYZ enterprise that we examined in this article ensured progress in a consistent manner during the pre-crisis period of 2006-2008. During these years, the company grew and secured a place for itself in the market. During the crisis period of 2008, it turned the crisis into an opportunity, thanks to the certain accounting policies it followed. Even though there was a decline during the first year following the crisis, afterwards the XYZ Company was able to start recovering. Owing to the accounting procedures implemented by it, XYZ accomplished to recover from the financial crisis with the least amount of damage during the post-crisis period of 2008-2010.

With this study conducted, it is observed that a company can go through a financial crisis period with the least amount of damage by employing the crisis management method and following correct accounting practices prior to and pursuant to the crisis. Thus, actually organizations determine their own destinies. Some companies panic during crisis periods and adopt flawed accounting policies in line with their own interests, which made them go through difficult processes and bring themselves to the point of bankruptcy. On the other side of the coin, golden firms exist such as the XYZ Company which implement correct accounting practices and guarantee their financial futures.

\section{REFERENCES}

AB Bakanlığı (2011); Avrupa Birliği Bakanlığı'nın Teşkilat ve Görevleri Hakkında Kanun Hükmünde Kararname; http://www.mevzuat.gov.tr/MevzuatMe tin/4.5.634.pdf, Say1:2.

Akerlof, G. and P.M. Romer (1993); Looting: The Economic Underworld of Bankruptcy for Profit, Brookings 
Papers on Economic Activity, No.2, 173.

Aysal, Mustafa (2009); Küresel Ekonomik Krizler ve Muhasebe Standartları, TMUD,

www.tmud.org.tr/UserFiles/File/AYSA NSUNUM.ppt (01.12.2009).

Barrett, P (2010); Performance Auditing What Value?, Public Money and Management, Vol. 30, No: 5, pp. 271 278.

Can, Ahmet Vecdi (2010); Krizin Muhasebesi ve Muhasebenin Krizi; http://archive.ismmmo.org.tr/docs/mali cozum/97malicozum/2\%20ahmet\%20v ecdi\%20can.pdf, Sayı : 97 - 2010.

Darman, Güler Manisalı (2004); Uluslararası Finansal Raporlama Standartlarının Kurumsal Yönetim Üzerindeki Etkileri; http://www.cgscenter.org/doc/UFRSNI NKURUMSALYONETIMUZERINDE ETKILERI.pdf, 5 Kasim 2004.

Daştan, Abdulkadir. (2009); Ekonomik Kriz Dönemlerinde Muhasebe Bilgi Sisteminin İşletmelerdeki Rolü ve Kriz Yönetimine Katkıs1", Muhasebe ve Denetime Bakış, Yı1: 9, Sayı: 28 (Nisan Say1s1), ss. 57-72.

Delice, Güven (2003); FINANSAL KRİZLER: TEORIK VE TARIHSEL BIR PERSPEKTIIf; http://iibf.erciyes.edu.tr/dergi/sayi20/de lice.pdf, Erciyes Üniversitesi İktisadi ve İdari Bilimler Fakültesi Dergisi, Sayı: 20, Ocak-Haziran 2003. -s. 5781.

Durukan, M.Banu (2009); Finansal Kriz ve Muhasebe: Kim İçin Muhasebe?; Mali Ufuklar 45 (Temmuz-Aralık 2009) : $11-28$

Frankel Jeffrey, A.,Rose, Andrew K (1996); Currency crashes in emerging markets: An empirical treatment; http://web.calstatela.edu/faculty/rcastil/ Econ462/Frankel.pdf, Journal of International Economics 41 (1996) 351-366.

Gökgöz, Ahmet (2012); Küresel Finansal Krizin Muhasebe Temelli Nedenleri Bağlamında Kurumsal Yönetim ve Muhasebe Meslek Etiğinin Önemi;
Atatürk Üniversitesi İktisadi ve İdari Bilimler Dergisi, Cilt: 26, Sayı: 3-4, 2012.

Kibritçioğlu, Bengi (2000); Finansal Krizler, Belirleyicileri, Öngörülebilirliği ve Yayılma Etkisi, Ankara: Hazine Müsteşarlığı, $\quad$ Yayınlanmamış Uzmanlık Tezi.

Köse, H. Ömer (2012); Küresel Krizle Mücadelede Denetimin Önemi ve Yüksek Denetim Kurumlarının Rolü; https://earsiv.anadolu.edu.tr/xmlui/bitst ream/handle/11421/145/2012-0307\%5b1\%5d.pdf?sequence $=1$ HYPERLINK , Anadolu Üniversitesi Sosyal Bilimler Dergisi, Cilt/Vol.: 12 Say1: 3 (93-108).

Pusti, Müge (2013); Krizlerin Anatomisi ve Türkiye'de 2001-2008 FinansalEkonomik Krizleri Üzerine Bir İnceleme; T.C. Atılım Üniversitesi Sosyal Bilimler Enstitüsü İşletme Yönetimi Anabilim Dalı, Ankara, 2013.

Saçan, Erdem (2014); Türkiye'de Bankacılar Açısından Gerçeğe Uygun Değer Muhasebesinin Yaşanan Finansal Krizlerdeki Rolü; http://archive.ismmmo.org.tr/docs/mali cozum/126malicozum/006_Erdem_SA C\%C4\%9FAN.pdf, Yildiz Teknik Üniversitesi, Sosyal Bilimler Enstitüsü, Muhasebe Finansman Doktora Program1.

Sönmez, Sinan (2013); Ekonomik ve Finansal Krizler Dünyasında Kısa bir Gezinti; http://ebulten.library.atilim.edu.tr/sayi/ 2013-10?sayfa=3, Cumhuriyet Gazetesi Bilim Teknoloji eki, Sayı:31, Ekim 2013.

Spence, M. (2008); Zor Zamanlardan Etkin Küresel Yönetim, Küresel Kriz ve Sonrası, Turkishtime, Om Yayıncılık, İstanbul, ss.25-27.

Stiglitz, J. (2008), "Çıkış Yolu”, Küresel Kriz ve Sonras1, Turkishtime, Om Yayıncılık, İstanbul, ss.5-12.

Topbaş, Neslihan (2009); Finansal Kriz Ortamında Bankaların Muhasebe Sistemlerinde Gerçeğe Uygun Değerleme Yönteminin Etkileri; 
https://www.tbb.org.tr/Dosyalar/Arastir ma_ve_Raporlar/neslihan.pdf,

Bankacılar Dergisi, Sayı 68, 2009.

Turgut, Ahmet (2007); Türleri, Nedenleri ve Göstergeleriyle Finansal Krizler; http://www.tuhis.org.tr/dergi/cilt20_say i4-5/cilt20_sayi4-5_bolum4.pdf,

TÜHIS İş Hukuku ve İktisat Dergisi, Cilt: 20, Sayı: 4 - 5, Kasým $2006 /$ Şubat 2007.

Türker, Masum (2009); 24.01.2009 Tarihli Muhasebe ve Finansman Derneği Olağan Kurulu, Konuşma Notları.

UNCTAD (1999); World Investment Report.

Yücel, Fatih ve Kalyoncu,Yücel (2010); Finansal Krizlerin Öncü Göstergeleri ve Ülke Ekonomilerini Etkileme Kanalları:Türkiye Örneği; http://dergiler.sgb.gov.tr/calismalar/mal iye_dergisi/yayinlar/md/159/FatihY\%C 3\%9CCEL.pdfMaliye Dergisi, Sayı 159,Temmuz-Aralık 2010. 